\title{
Omphalocele and gastroshisis: a 14-year study
}

\begin{abstract}
Introduction: Omphalocele and gastroschisis are developmental defects of the anterior abdominal wall, which have only recently been categorized as separate entities. In both cases, it is a herniation of abdominal organs through appropriate defects of the anterior abdominal wall. It is considered that the omphalocele are quite often developmental anomalies and are often associated with other developmental disorders, unlike gastroschisis, which usually occur isolated.
\end{abstract}

Aims of the study: To determine the frequency of cases of omphalocele and gastroschisis in the Clinical Center of Banja Luka in the period from 2000 to 2013.

Patients and methods: Insight into medical records, a retrospective analysis of all cases of congenital defects of the anterior abdominal wall at the Clinical Center of Banja Luka was done from the year 2000-2013. The analysis included all cases of omphalocele and gastroschisis, and prematurity, associated anomalies, the rate of mortality in the first year, exposure to environmental factors during pregnancy, maternal diabetes, maternal age, and familiar occurence of these anomalies were taken into consideration. Cases of „the prune belly“ syndrome and umbilical hernia were not included in this research.

Results: During the period 2000-2013, there was a total of 19 cases of omphalocele, of which eigth live births. In the same period there was 14 cases of gastroschisis, and there was seven children born alive with this defect. In 73 percent of omphalocele cases there was associated anomalies, while this rate at gastroschisis was significantly lower and amounted to 28 percent. Among the live births, prematurity rate was 37.5 percent for the omphalocele group and 57 percent for the group of gastroschisis. The mortality rate in the first year of life was 25 percent for omphalocele and 14 percent for gastroshisis. In all these cases, the cause of death was not directly related to abdominal defect, but the associated complications (respiratory distress in the first place). Half of the mothers from both groups stated that they had used some medicines or consumed cigarettes during pregnancy. There was also a single incident of gestational diabetes in the group of omphalocele and one case of a positive family history from the gastroschisis group.

Discussion: In this study, the relation of omphalocele and gastroshisis was 19/14 or 1.3:1, compared to the expected 3:2 ratio in the world literature. Other studies around the world show a higher incidence of gastroschisis and lower incidence of omphalocele. We had no reported cases of stillbirths in omphalocele group although, in the world literature, data of 11-12 percent were noticed. The reason for this discrepancy could be a different criteria for stillbirth compared to abortion, and perhaps the reporting was biased. The percentage of associated anomalies was higher in group of omphalocele, and similar results were reported in other studies. The mortality rate in thefirst year of life in a group of omphalocele was much higher when compared to gastroschisis group. For unknown reasons, stillborn children with omphalocele were not represented in this study.

\section{Mirko Raković1, Zlatko Maksimović ${ }^{2}$, Dragan Danelišen, Denis Pašalić1}

${ }^{1}$ Department of Pediatric Surgery, University Hospital Clinical Center of Banja Luka

${ }^{2}$ Health Center Bijeljina

\section{Contact address:}

Raković Mirko

Department of Pediatric Surgery, University Hospital Clinical Center of Banja Luka

Banja Luka, 12 beba bb

email: drmirkorakovic@hotmail.com
Submitted: October 23rd, 2014 Accepted: December 29th, 2014 
Conclusion: 33 patients with omphalocele and gastroschisis, treated in this study, confirmed the world's medical reports that the incidence of gastroschisis increased when compared to omphalocele. These statistics should have an impact on the textbooks which still represent omphalocele as a significantly more frequent anomalies.

Keywords: omphalocele, gastroschisis, birth defects, frequency

\section{Introduction}

Omphalocele and gastroschisis represent developmental defects of the anterior abdominal wall first described in the 16th century. However, these two conditions have only recently been categorized as separate entities. In 1953 Moore and Strokes ${ }^{2}$ defined two separate pathological conditions, and in 1963 Duhamel $^{3}$ highlighted their different pathogenesis and clinical manifestations. Omphalocele is a congenital herniation of the abdominal cavity through a central defect in the abdominal wall into amniotic sac layers. (Picture 1.)

Picture 1: Omphalocele (intestines in amniotic sac layers)

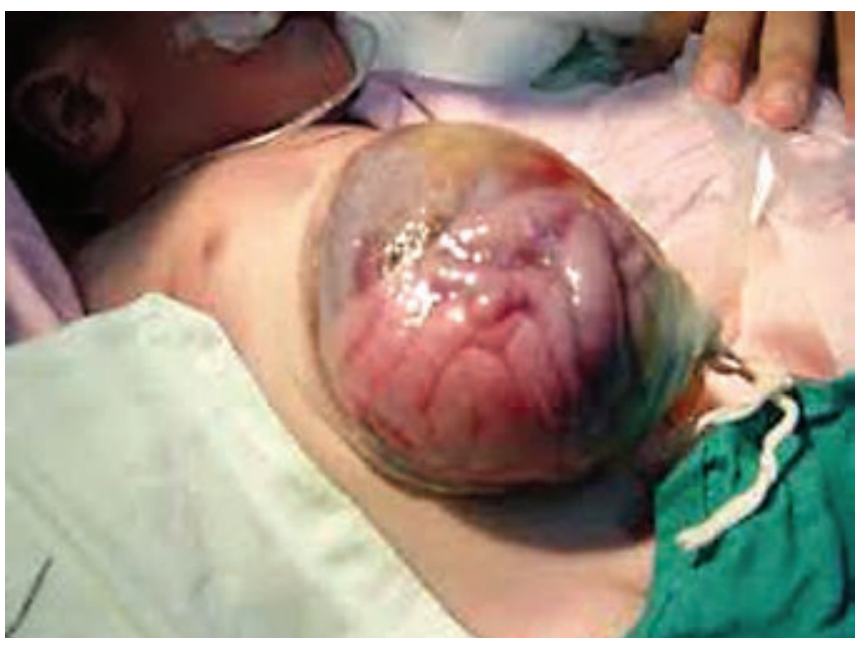

In minor defects there is a protrusion of convolutions of the small intestine into the umbilical cord (umbilical cord hernia), while in major defects, the content consists of intestines and other abdominal organs, including the liver and spleen (omphalocele). In gastroschisis, there is a minor defect of the anterior abdominal wall $(1-2 \mathrm{~cm})$, usually at the forehand of the umbilical cord insertion. (Picture 2.)
Picture 2: Gastroschisis (herniation of intestine without a hernia sac)

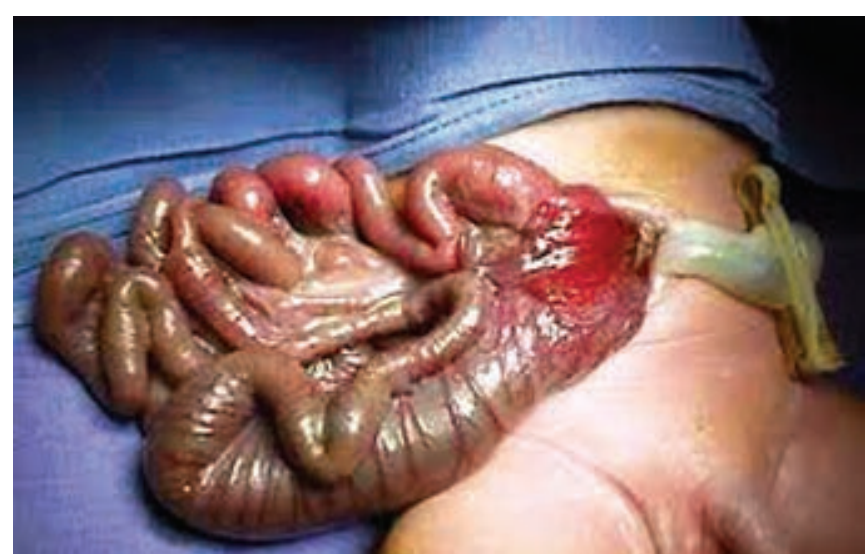

Between umbilicus and the umbilical cord, which is usually of normal structure, there is a bridge of the intact skin. Throughout this defect usually only convolutions of the small intestine eviscerate, so they are found in the amniotic fluid. ${ }^{4}$ Nowadays, omphalocele is a more common developmental defect, occurring in 1:400o births, compared to 1 : 6000 births with gastroschisis. ${ }^{5,6}$ Gastroschisis are usually isolated anomalies ${ }^{7}$, while omphalocele is often associated with chromosomal abnormalities and other congenital anomalies. ${ }^{8}$ A long-term prognosis in neonates with gastroschisis is significantly better than those with omphalocele, where the survival rate is 50 to $60 \%$, and there are usually chronic medical problems..$^{9,10}$

\section{The aim of this study}

To determine the frequency of cases of omphalocele and gastroschisis at the University Hospital Clinical Center Banja Luka in the period from 2000 to 2013. Furthermore, to determine the existence of associated anomalies and finally, to assess the importance of specific etiological factors for the occurence of these anomalies. 


\section{Patients and Methods}

Having reviewed the medical records of the Clinic for Pediatric Surgery, Pediatric Clinic and Clinic of Gynecology and Obstetrics of the University Hospital Clinical Center of Banja Luka, a retrospective analysis was conducted based on all the cases of congenital defects of the anterior abdominal wall by a type of omphalocele and gastroschisis. Prematurity, associated anomalies, 1-year mortality rate, exposure to environmental factors during pregnancy, maternal diabetes, maternal age and occurrence of these anomalies within a family were taken into account in the analysis of each case. Polyhydramnios, oligohydramnios and complications of prematurity were not monitored as associated anomalies. Cryptorchidism was included in the associated anomalies in babies born at term. Prematurity was defined as a birth before 37 weeks of gestation. Miscarriage was defined as spontaneous abortion within 20 weeks of gestation. The analysis included all cases of gastroschisis and omphalocele (isolated or with associated anomalies), but excluded cases of "prune belly" syndrome and umbilical hernia. Diagnoses of omphalocele and gastroschisis in neonates, together with associated anomalies were confirmed through physical examination by a pediatrician and children's surgeon. In the cases of prenatal diagnosis, abdominal wall defects were discovered during ultrasound examinations during pregnancy. The pathology / autopsy data provide additional information in pregnancies completed with stillbirth, miscarriage or elective termination.

\section{Results}

In the period from 2000 to 2013 , there were 19 cases of omphalocele, out of which, there were eight cases of live borns. 14 cases were diagnosed prenatally, and in five cases the diagnosis was made after birth. (Table 1.)

Table 1: Cases of omphalocele and gastroschisis at the University Hospital Center Banja Luka in the period 2000-2013.

\begin{tabular}{lcc}
\hline & Omphalocele group & Gastroschisis group \\
\hline Prenatal Dg & 3 & 3 \\
Number of births & 0 & 1 \\
Number of stillborns & 5 & 2 \\
Elective pregnancy & 6 & 3 \\
termination & & \\
Miscarriages & 5 & 4 \\
\hline Dg after birth & 0 & 1 \\
Number of births & 19 & 14 \\
Number of stillborns & 8 & 7 \\
\hline Total & & \\
\hline Total number of & births &
\end{tabular}

Omphalocele group Gastroschisis group
Of the 14 cases of prenatal diagnosis, there were three cases of live borns. Five pregnancies were electively aborted, and the remaining six were miscarriages.In cases of miscarriages, four fetuses showed a lag in intrauterine development and had associated anomalies, and two fetuses had isolated omphalocele.

During the same period, there were 14 cases of gastroschisis, nine were diagnosed in prenatals and five were diagnosed after birth. (Table 1.) .

There were seven births with this defect. In two cases, the child was stillborn. One stillbirth had isolated gastroschisis, and the other had multiple anomalies including hydrops and mutual syndactyly.

In 14 out of 19 cases of omphalocele there were associated anomalies (73\%), and the most common among them were congenital heart defects (26\%). In contrast, only 4 out of 14 cases of gastroschisis had associated anomalies (28\%). (Figure 1.).

Figure 1: Graphical representation of differences in omphalocele and gastroschisis group in relation to the prematurity rate, mortality in the first year aexistence of associated anomalies

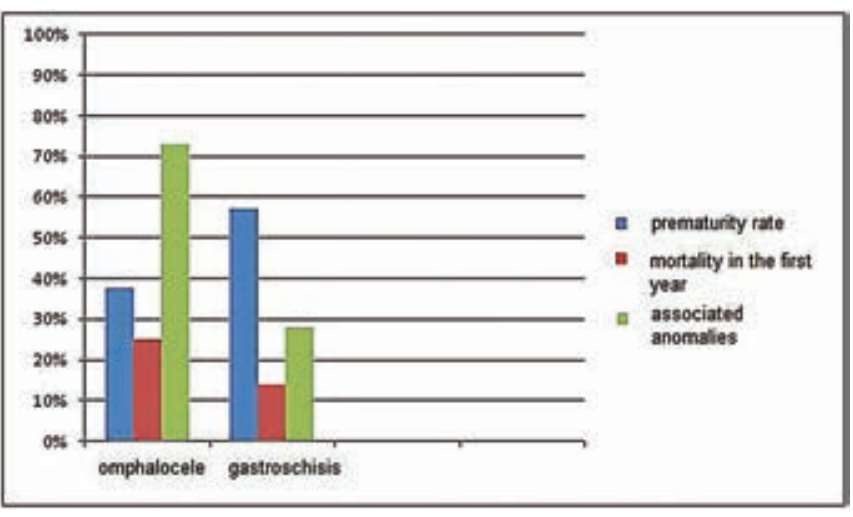

Among the eight births with omphalocele, prematurity rate was $3 / 8(37.5 \%)$; for seven births with gastroschisis prematurity rate was $4 / 7$ (57\%). (Figure 3.)

The mortality rate during the first year of life in the group of omphalocele was 2/8 (25\%). The cause of death was not directly tied to omphalocele (in one case the cause was respiratory distress and in the second, congenital heart disease). In gastroschisis group, the mortality rate during the first year of life was $1 / 7$ (14\%). The cause of death was postoperative complications. (Figure 3.).

In three cases omphalocele was wrongly diagnosed during ultrasonography as gastroschisis, and in one case of gastroschisis, omphalocele was mistakenly diagnosed. In the omphalocele group, 9 out of 19 mothers (47\%) reported having used medicines during pregnancy, 
whereas in the gastroschisis group medication exposure was $7 / 14(50 \%)$. In the omphalocele group, 3 mothers (16\%) consumed cigarettes during pregnancy compared with 2 mothers (14\%) in the gastroschisis group. One case of gestational diabetes was described within the omphalocele group (0.5\%), and one case of positive family history in the gastroschisis group (0.7\%).

\section{Discussion}

In this study, the ratio of omphalocele and gastroschisis was 19/14 or 1.3: 1, compared to the expected ratio of 3: 2 in the world literature. Regargding the births, the ratio was 1: 1, that is, eight cases of omphalocele and seven cases of gastroschisis. Other studies around the world show an increase in the frequency of gastroschisis, and decrese in the appearance of omphalocele..$^{5,6,7}$ Rankin and the others ${ }^{11}$ reported an increased incidence of gastroschisis without a corresponding change in the appearance of omphalocele. Theories in favor of these changes include the incidence of etiologic agents, incorrect classification, meager family history and a higher risk of occurrence of these defects in families. ${ }^{12}$

In this study, there were no reported cases of stillbirths with exomphalos, although the world literature data show $11-12 \%$ of the abovementioned cases.${ }^{9}$ However, excluding elective abortions and pregnancies of unknown outcome, the rate of spontaneous abortions was $31 \%$. It could have been that differences in the criteria for stillbirth in relation to abortion contributed to this discrepancy, and there could have been a bias in reporting. The percentage of associated anomalies was $73 \%$ for omphalocele, compared with $28 \%$ for gastroschisis. Similar results were published in previous studies, ${ }^{7,8,12}$, where congenital heart diseases were most commonly associated with abdominal wall defects. ${ }^{7}$

In this study, prematurity rate amounted to $37.5 \%$ for omphalocele and $57 \%$ for gastroschisis. Reports of world studies show values ranging from $40 \%$ to $60 \%$ for gastroschisis, compared to $10 \%$ to $23 \%$ for omphalocele. ${ }^{7}$ Perhaps differences in the criteria for prematurity can be the reasons for the higher rate of preterm birth in the omphalocele group in comparison with other studies.

The mortality rate in the first year of life in the omphalocele groupwassignificantlyhigherthaninthegastroschisisgroup. The risk for familial occurrence of nonsyndromic defects of the anterior abdominal wall was considered to be low $(<1 \%)$. However, Torfs and Curry ${ }^{13}$ found $3.5 \%$ risk of familial occurrence of gastroschisis by expanding pedigree to the second degree relatives. They emphasized that incomplete family history resulted in unreported cases of familial occurrence of these anomalies. ${ }^{13}$ Also, incorrect diagnosis, and information in the medical reportscould have affected the actual frequency of occurrence of congenital defects of the anterior abdominal wall within the family. Theories on the method of inheritance ranged from Mendelian monogenic to multifactorial. ${ }^{8,13}$

In this study, mothers in the gastroschisis group were younger than the mothers in the omphalocele group. 37\% of mothers younger than 20 were in the gastroschisis group. In the same group there were no mothers older than 40 . Other world studies show similar results: the incidence of gastroschisis is the highest among the mothers under 20 years of age and sharply decreases with increasing age of the mother. ${ }^{14,15}$ Less than $7 \%$ of mothers in the groups were older than 29 years. The reason for younger age of the mothers is unknown. ${ }^{15}$

For unknown reasons, stillborn children with omphalocele were not represented in this study. Also, graphical representations of the studies are susceptible to bias in the interpretation of data, but this bias is limited by physical examination of newborns by the same doctor, as well as analysis of sonographicfindingsand histopathologicreports.

\section{Conclusion}

33 patients with omphalocele and gastroschisis, treated in this study, confirm the reports of medical facilities in the world that the incidence of gastroschisis increases in comparison to omphalocele ${ }^{5,6,14}$ and gastroschisis may be more common than isolated omphalocele with births. Although there is no clear reason for the change in trend of occurrence of these anomalies, statistical data from these studies should have an effect on textbooks in which omphalocele are still considered to be more common anomalies.

\section{References}

1. Duke, Duane S., and Marshall Z. Schwartz. "Omphalocele and gastroschisis.”Pediatric Surgery. Springer Berlin Heidelberg, 2009. 619-627.

2. Moore TC, Stokes GE. Gastroschisis: Report of two cases treated by a modification of the gross operation for omphalocele. Surgery 1953;33:112-120.

3. Duhamel B. Embryology of exomphalos and allied malformations. Arch Dis Child 1963;38:142-147.

4. Vučkov Š, Kvesić A. Selected chapters from the Pediatric surgery, Mostar 2005, 97-102.

5. Loane, M., Dolk, H., \& Bradbury, I. (2007). Increasing prevalence of gastroschisis in Europe 1980-2002: a phenomenon restricted to younger mothers?. Paediatric and perinatal epidemiology, 21(4), 363-369.

6. Collins, Sonya R., et al. "The rising prevalence of gastroschisis and omphalocele in Tennessee." Journal of pediatric surgery 42.7 (2007): 1221-1224.

7. Stoll C, Alembik Y, Dott B, Roth M-P. (2008). Omphalocele and gastroschisis and associated malformations. Am J Med Genet Part A 146A:1280-1285. 
8. Chen, C. P. (2007). Chromosomal abnormalities associated with omphalocele.Taiwanese Journal of Obstetrics and Gynecology, 46(1), 1-8.

9. Henrich, K., Huemmer, H. P., Reingruber, B., \& Weber, P. G. (2008). Gastroschisis and omphalocele: treatments and longterm outcomes. Pediatric surgery international, 24(2), 167-173.

10. Fratelli, N., et al. "Outcome of antenatally diagnosed abdominal wall defects.”Ultrasound in Obstetrics \& Gynecology 30.3 (2007): 266-270.

11. Rankin J, Dillon E, Wright C. Congenital anterior abdominal wall defects in the north of England, 1986-1996: occurrence and outcome. Prenat Diagn 1999;19:662-668.
12. Kumar, H. R., Jester, A. L., \& Ladd, A. P. (2008). Impact of omphalocele size on associated conditions. Journal of pediatric surgery, 43(12), 2216-2219.

13. Torfs CP, Curry CJ. Familial cases of gastroschisis in a populationbased registry. Am J Med Genet 1993;45:465-467.

14. Mac Bird, T., et al. "Demographic and environmental risk factors for gastroschisis and omphalocele in the National Birth Defects Prevention Study.”Journal of pediatric surgery 44.8 (2009): 15461551.

15. Chircor, L. I. D. I. A., Rodica Mehedinti, and M. I. H. A. E. L. A. Hincu. "Risk factors related to omphalocele and gastroschisis.” Rom J Morphol Embryol50.4 (2009): 645-9.

\section{Omfalocele i gastroshize: 14-godišnja studija}

\section{SAŽETAK}

Uvod: Omfalocele i gastroshize su razvojni defekti prednjeg trbušnog zida, koji su tek nedavno kategorisani kao zasebni entiteti. U oba slučaja se radi o hernijaciji organa trbušne duplje kroz odgovarajuće defekte prednjeg trbušnog zida. Smatra se da su omfalocele dosta češće razvojne anomalije i često su udružene sa drugim razvojnim poremećajima, za razliku od gastroshiza koje se obično javljaju izolovano.

Cilj rada: Odrediti učestalost slučajeva omfalocela i gastroshiza u Kliničkom centru Banja Luka u periodu od $2000 .-2013$. godine.

Pacijenti i metode: Uvidom u medicinsku dokumentaciju učinjena je retrospektivna analiza svih slučajeva urođenih defekata prednjeg trbušnog zida u Kliničkom centru Banja Luka, u periodu od 2000.-2013. godine. Analizom su obuhvaćeni svi slučajevi omfalocela i gastroshiza, a u obzir je uziman prematuritet, pridružene anomalije, stopa mortaliteta u prvoj godini, izloženost faktorima okoline tokom trudnoće, dijabetes majke, starosna dob majke, kao i familijarna pojava ovih anomalija. Slučajevi „prune belly" sindroma i umbilikalnih hernija nisu obuhvaćeni ovim ispitivanjem.

Rezultati: U periodu od 2000.-2013. bilo je ukupno 19 slučajeva omfalocele, od toga osmoro živorođene djece. U istom periodu bilo je ukupno 14 slučajeva gastroshize, a živorođene djece sa ovim defektom bilo je sedam. U 73\% slučajeva omfalocele, postojale su udružene anomalije, dok je taj procenat kod gastroshiza bio znatno manji i iznosio je 28\%. Među živorođenom djecom stopa prematuriteta iznosila je 37.5\% za grupu omfalocele, a za grupu gastroshiza 57\%. Stopa mortaliteta u prvoj godini života iznosila je 25\% za omfalocele i 14\% za gastroshize. I u jednim i u drugim slučajevima uzrok smrti nije bio vezan direktno za abdominalni defekt, već za prateće komplikacije (respiratorni distres na prvom mjestu). Polovina majki iz obe grupe izjavila je da je tokom trudnoće koristila neke lijekove ili konzumirala cigarete. Opisan je i jedan slučaj gestacijskog dijabetesa u grupi omfalocele i jedan slučaj pozitivne porodične anamneze iz grupe gastroshize.

Diskusija: U ovoj studiji odnos omfalocela i gastroshiza bio je19/14 ili 1.3:1, u odnosu na očekivani odnos 3:2 u svjetskim literaturama. I druge studije širom svijeta pokazuju povećanje učestalosti gastroshiza i pad incidence omfalocela. Nismo imali prijavljenih slučajeva mrtvorođene djece sa omfalocelom iako u svjetskoj literaturi postoje podaci od 11-12\%. Razlog ove neusklađenosti mogu biti različiti kriterijumi za mrtvorođenost u odnosu na pobačaj, a možda postoji i pristrasnost u izvještavanju. Procenat udruženih anomalija je veći kad su u pitanju omfalocele, a slični rezultati objavljeni su i u drugim studijama. Stopa smrtnosti u prvoj godini života je u grupi omfalocele znatno veća u odnosu na grupu gastroshiza. Iz nepoznatih razloga mrtvorođena djeca sa omfalocelom nisu zastupljena u ovoj studiji.

Zaključak: 33 pacijenta sa omfalocelom i gastroshizom, obrađena u ovoj studiji, potvrđuju medicinske izvještaje u svijetu koji ukazuju da se incidenca gastroshiza povećava u odnosu na omfalocelu, i ti statistički podaci bi trebalo dase odraze i na udžbenike u kojima se omfalocele i dalje predstavljaju kao značajno češće anomalije.

Ključne riječi: omfalocela, gastroshiza, urođene mane, učestalost 